\title{
2021 Handbook of Florida Water Regulation: Clean Water Act ${ }^{1}$
}

\author{
Michael T. Olexa, Tatiana Borisova, and Jana Caracciolo²
}

\section{Preface}

This handbook is designed to provide an accurate, current, and authoritative summary of the principal federal and state (Florida) laws that directly or indirectly relate to agriculture. This handbook provides a basic overview of the many rights and responsibilities that farmers and farmland owners have under both federal and state laws as well as the appropriate contact information to obtain more detailed information. However, the reader should be aware that because the laws, administrative rulings, and court decisions on which this handbook is based are subject to constant revision, portions of this publication could become outdated at any time. Several details of cited laws are also left out due to space limitations. This handbook is provided as an educational text for those interested in water use and water resource issues in Florida.

This handbook is distributed with the understanding that the authors are not engaged in rendering legal or other professional advice, and the information contained herein should not be regarded as a substitute for professional advice. This handbook is not all inclusive in providing information to achieve compliance with the federal and state laws and regulations governing water protection. For these reasons, the use of these materials by any person constitutes an agreement to hold harmless the authors, the UF/IFAS Center for Agricultural and Natural Resource Law, and UF/IFAS Extension for any liability claims, damages, or expenses that may be incurred by any person as a result of reference to or reliance on the information contained in this handbook. Note: UF/IFAS is the acronym for University of Florida, Institute of Food and Agricultural Sciences.

\section{CWA Overview}

The Clean Water Act (CWA) provides the framework for regulating pollution loading to the waters of the United States. It is directed at maintaining and restoring the chemical, physical, and biological integrity of waters of the United States. The regulation of pollution is implemented through a system of water quality standards for pollutants potentially entering waterbodies, and a system of pollution control permits and wastewater standards for municipalities and industries. For waterbodies not meeting water quality standards, CWA requires that a pollution cap should be established and a plan for meeting this cap and restoring waterbodies to meet water quality standards should be developed (referred to as Total Maximum Daily Load, TMDL).

\section{What are the waters of the United States?}

CWA only applies to the water bodies classified as "the waters of the United States" or WOTUS. The definition of

1. This document is FE582, one of a series of the Food and Resource Economics Department, UF/IFAS Extension. Original publication date October 1998. Most recent revision April 2021. Visit the EDIS website at https://edis.ifas.ufl.edu for the currently supported version of this publication.

2. Michael T. Olexa, professor, Food and Resource Economics Department, and director, UF/IFAS Center for Agricultural and Natural Resource Law; Tatiana Borisova, associate professor, Food and Resource Economics Department; and Jana Caracciolo, student, Levin College of Law; UF/IFAS Extension, Gainesville, FL 32611.

The Institute of Food and Agricultural Sciences (IFAS) is an Equal Opportunity Institution authorized to provide research, educational information and other services

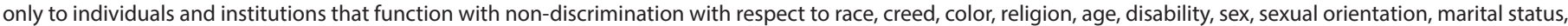

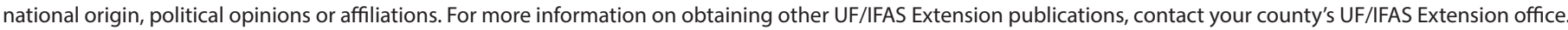
U.S. Department of Agriculture, UF/IFAS Extension Service, University of Florida, IFAS, Florida A \& M University Cooperative Extension Program, and Boards of County Commissioners Cooperating. Nick T. Place, dean for UF/IFAS Extension. 
WOTUS has gone through many changes over time. In 2020, the federal United States Environmental Protection Agency (EPA) and the Army Corps of Engineers (USACE) published a new rule entitled "The Navigable Waters Protection Rule: Definition of 'Waters of the United States". This rule states that WOTUS includes:

1. The territorial seas and waters, which are currently used, or were used in the past, or may be susceptible to use in interstate or foreign commerce, including waters subject to the ebb and flow of the tide.

\section{Tributaries.}

3. Lakes and ponds, and impoundments of jurisdictional waters.

\section{Adjacent wetlands.}

These four categories are what the 2020 rule refers to as jurisdictional water. The 2020 rule explicitly excludes the following from the definition of WOTUS and from jurisdictional waters:

1. Waters or water features that are not identified as jurisdictional waters.

2. Groundwater, including groundwater drained through subsurface drainage systems.

3. Ephemeral features that flow only in direct response to precipitation, including ephemeral streams, swales, gullies, rills, and pools.

4. Diffuse stormwater runoff and directional sheet flow over upland.

5. Ditches that are not traditional navigable waters, tributaries, or that are not constructed in adjacent wetlands, subject to certain limitations.

\section{Prior converted croplands.}

7. Artificially irrigated areas that would revert to upland if artificial irrigation ceases.

8. Artificial lakes and ponds that are not jurisdictional impoundments and that are constructed or excavated in upland or non-jurisdictional waters.

9. Water-filled depressions constructed or excavated in upland or in non-jurisdictional waters incidental to mining or construction activity, and pits excavated in upland or in non-jurisdictional waters for the purpose of obtaining fill, sand, or gravel.

10. Stormwater control features constructed or excavated in upland or in non-jurisdictional waters to convey, treat, infiltrate, or store stormwater runoff.

11. Groundwater recharge, water reuse, and wastewater recycling structures constructed or excavated in upland or in non-jurisdictional waters.

\section{Waste treatment systems.}

For more on the definition of "waters of the United States", see EPA's website: https://www.epa.gov/cleanwaterrule/ definition-waters-united-states-under-clean-water-act.

\section{What are the rules for NPDES permits?}

According to CWA, any discharge of pollutants through a point source into waters of the United States is prohibited unless the source operator has a valid National Pollutant Discharge Elimination System (NPDES) permit. A point source is any discernable, confined, and measurable conveyance from which a pollutant is or may be discharged. A point source may be a ditch or pipe discharging pollutants, a container being rinsed of pollutants, a concentrated animal feeding operation, a vessel, or any other source that releases or may release pollutants into a specific area.

NPDES permits include limits on discharge, monitoring and reporting requirements, and other provisions. NPDES permits impose two types of limitations on point-source polluters:

1. Technology-Based Effluent Limitations. Limits placed on the contents of the effluent based on the best practicable treatment technology available to control pollutants.

2. Water-Quality-Based Effluent Limitations. Limits depend on the standards established for the quality of the waterbody (including groundwater bodies) into which the discharge takes place (cases are viewed on a case-by-case basis).

To search the database of NPDES permits, see the EPA website: https://echo.epa.gov/. 


\section{What are the rules for dredge and fill?}

CWA requires separate permits for the discharge of dredge and fill material into navigable waters or wetlands. Dredge and fill permits are issued by ACE, but EPA has veto power over ACE-issued permits.

\section{What are the rules for oil and hazardous substances?}

CWA also prohibits discharges of oil or specified hazardous substances. It further requires that all spills be reported immediately if the amount spilled is greater than the individual "reportable quantities" that EPA has specified for each of around 300 designated "hazardous substances." Reporting spills quickly to the Emergency Superfund Branch (see FE615, Appendix, for telephone numbers) insulates the offender from criminal prosecution but not from civil liability. The CWA also provides for the development of a National Contingency Plan to efficiently remove spills.

\section{What are the rules for other sources of pollution?}

Runoff from agricultural fields and return flow from agricultural irrigation systems (as well as stormwater from mining operations or oil and gas exploration, production, processing, or transmission) are not point sources, and they are not required to have NPDES permits. They are referred to as "nonpoint sources" because pollution loading from them does not come from a specific source; rather, it is dispersed and originates from various places (see FE617, Notes and Glossary, for a definition of nonpoint sources).

The CWA addresses nonpoint sources in Section 319(h) by proving funds to designated state agencies to implement approved nonpoint source management programs. Examples of fundable projects include demonstration and evaluation of Best Management Practices (BMPs), nonpoint pollution reduction measures in priority watersheds, groundwater protection from nonpoint sources, and public education programs on nonpoint source management.

\section{What are the rules under TMDL?}

The Impaired Waters and Total Maximum Daily Load (TMDL) Program of the CWA is a two-step process to restore and protect water quality. First, states are required to develop a list of impaired waters. These are water bodies that are not meeting water quality standards based on collected monitoring data. States are required to update and resubmit their impaired waters list every two years.

Second, states must establish priority rankings for waters on the impaired lists and develop TMDLs for these waters. A TMDL is a calculation of the maximum amount of a pollutant that can be present in a water body and still meet water quality standards. TMDL plans also identify pollution caps for various sources, and propose a set of measures that those contributing to the water pollution should take to restore the water body to meet water quality standards.

To learn more about water bodies in the area where you live, see https://www.epa.gov/tmdl/ impaired-waters-and-tmdls-resources-tools-and-databases.

\section{Who enforces CWA?}

CWA is generally enforced by the federal EPA (note that dredge and fill permitting is enforced by the federal ACE). States are authorized under CWA to establish their own standards for allowable levels of pollutants as long as such standards are at least as stringent as those mandated by EPA. The EPA may also delegate permitting authority to a state. Florida has been delegated enforcement of portions of CWA, including NPDES permitting in all areas of the state except for tribal lands.

\section{What are the penalties under CWA?}

The extent of criminal liability under CWA depends primarily on whether the violator is simply negligent (with fines up to $\$ 25,000$ per day, one year of imprisonment, or both), knows of his or her violation (with fines up to $\$ 50,000$ per day, three years of imprisonment, or both), or knowingly places others in serious imminent danger (with fines up to $\$ 250,000$ total, 15 years of imprisonment, or both). All these penalties may be doubled for subsequent violations and some may be greater for corporations. Under CWA Section 309(c), criminal liability can apply to any person who violates the act, including NPDES permit holders.

CWA also provides for civil and administrative penalties for each violation of CWA or NPDES permit. Civil penalties can be imposed for up to $\$ 25,000$ per day for each violation. Administrative penalties can be imposed for up to $\$ 125,000$. Injunctive relief (which forces violators to cease polluting) or other court-ordered relief is also available. 


\section{Sources}

33 United States Code, Sections 1251 to 1387

Federal Register Vol. 85, No. 77 (April 21, 2020, page

22250)

South Florida Water Management District v. Miccosukee

Tribe of Indians, 541 US 95 (2004)

\section{Acknowledgments}

The authors are indebted to the personnel of both state and federal agencies who provided their time and advice in the preparation of this handbook. We acknowledge Carol Fountain and Susan Gildersleeve at the University of Florida for their assistance in editing this handbook. We also acknowledge funding received for updating this publication from the James S. and Dorothy F. Wershow UF/ IFAS Center for Agricultural and Natural Resource Law Endowment. 